\author{
Marek Delong \\ Univesity of Rzeszow \\ Department of Political Science \\ e-mail: m-delong77@tlen.pl
}

\title{
Aspekty etyczne polskiej transformacji gospodarczej w enuncjacjach Konferencji Episkopatu Polski
}

\section{Moral and Ethical Aspects of the Polish Transition from Communism in the Enunciations of the Polish Episcopate}

The Polish Episcopate critically assessed the social and economic situation in Poland in the period of the transition from communism to democracy and freemarket economy. Privatizations led to production being stopped and an increase in unemployment. Profit became the measure of labor, not human dignity. The economic and social reality was dominated by the treatment of economics and financial success as the highest values, and the dissemination of the opinion that in politics and economics there are no values.

The political elites showed an inability to develop long-term strategies for getting out of the crisis. The disappearance of the morality of many representatives of public life, which manifested itself in universal corruption and the aspiration to improve their social status as soon as possible, contributed to this state of affairs. As a result, there was a crisis of the idea of the common wealth and an increase in crime.

The social crisis was particularly visible in moral attitudes, social behaviour, and in the economic sphere, public finance, on the labour market, and in the quickly progressing social stratification.

Keywords: Polish Episcopate, ethics, economy

JEL Classification: A13, Z12 


\section{Wprowadzenie}

Konferencja Episkopatu Polski jest głównym organem Kościoła hierarchicznego, mającym charakter kolegialny. Posiada osobowość prawną kanoniczną, która jest uznawana przez państwo polskie. Jej decyzje mają bardzo istotne znaczenie dla funkcjonowania Kościoła katolickiego w polskim życiu publicznym. Wydaje dokumenty, które stanowią rozwinięcie nauczania społecznego Kościoła oraz nawiązuje dialog z władzami politycznymi.

Zadaniem Konferencji Episkopatu Polski jest nauczanie i wyjaśnianie podstawowych problemów społecznych w duchu nauki chrześcijańskiej. Po 1989 roku była ona najbardziej aktywna w takich kwestiach, jak model stosunków państwo - Kościół, konkordat, konstytucja, wybory, środki społecznego przekazu, nauczanie religii w szkołach, rewindykacja majątku kościelnego, ochrona życia poczętego, a także w debacie poprzedzającej integrację Polski z Unią Europejską. Wiele enuncjacji wpisywało się $\mathrm{w}$ problemy relacji między państwem a Kościołem, wpływu decyzji wyborczych katolików na kształtowanie się systemu demokratycznego, zagadnień związanych z nauką społeczną Kościoła, takich jak praca, bezrobocie, a także kwestie katechetyczne i wychowawcze oraz bioetyczne ${ }^{1}$.

Konferencja Episkopatu Polski koncentrowała się na problemach społecznych, sytuacji rodziny, jej kondycji moralnej i warunkach egzystencji materialnej. Akcentowała problemy bezrobocia, pauperyzacji społecznej, potrzebę wychowania młodego pokolenia w oparciu o wartości chrześcijańskie i patriotyczne. Zwracała uwagę na potrzebę realizacji skutecznej, długofalowej polityki prorodzinnej.

Celem niniejszego artykułu jest przedstawienie aspektów etycznych polskiej transformacji gospodarczej w świetle enuncjacji Konferencji Episkopatu Polski. Był to istotny element programowy oficjalnych wypowiedzi Kościoła hierarchicznego w Polsce, który uznawał tę kwestię za szczególnie ważną w dobie przyspieszonych przemian. Podkreślano, że transformacja gospodarcza przyniosła ogromne koszty społeczne, gdyż jej przebieg wiązał się z brakiem poszanowania dla podstawowych wartości i łamaniem zasad moralności chrześcijańskiej.

Spośród wykorzystanych metod badawczych szczególne znaczenie miała analiza systemowa oraz metoda genetyczno-historyczna, chociaż nie jest ona konsekwencją pogłębionych, archiwalnych badań źródłowych i stanowi uzupełnienie metody analizy systemowej.

\section{Stanowisko Konferencji Episkopatu Polski wobec przemian gospodarczych}

Transformacja gospodarcza jest procesem tworzenia nowego systemu gospodarczego, zainicjowanym przez formalną zmianę ustroju politycznego, czyli jest elementem transformacji ustrojowej. Proces przemian w Polsce został zapocząt-

\footnotetext{
${ }^{1}$ K. Skowronek, Między sacrum a profanum. Studium językoznawcze listów pasterskich Konferencji Episkopatu Polski (1945-2005), LEXIS, Kraków 2006, s. 317.
} 
kowany w 1989 roku, ale problematyczne jest określenie daty końca transformacji gospodarczej. Wielu komentatorów uważa, że jeszcze się ona nie dokonała. Nie zmienił tego również fakt wejścia Polski do Unii Europejskiej w 2004 roku, bo państwo wciąż prowadzi w niektórych obszarach aktywną politykę gospodarcząa ${ }^{2}$.

Konferencja Episkopatu Polski zachowywała wyraźną powściągliwość wobec przemian gospodarczych związanych z prywatyzacją i przekształceniami własnościowymi. Mimo oczekiwań społecznych oraz zarzutów polityków bardzo rzadko wypowiadała się na tematy gospodarcze. W warunkach polityzacji polskiej prywatyzacji jednoznaczne stanowisko hierarchii kościelnej mogłoby być postrzegane jako przejaw politycznego zaangażowania ${ }^{3}$.

Charakteryzując stosunek Kościoła do przemian gospodarczych, biskup Tadeusz Pieronek przyznał, że Kościół dopuścił się na tym polu wyraźnych zaniedbań:

Przeważało przekonanie, że nie należy hamować reform, nie powinno się utrudniać rządowi działań, których koniecznym skutkiem ubocznym było pogłębienie rozwarstwienia na bogatych i biednych. Kościól zreszta wierzyl, że działania te na dalsza mete poprawia sytuacje gospodarcza, a przy tym byt w niezręcznej sytuacji politycznej, niepozwalajacej mu na przeciwstawienie się rzadom wywodzacym się z ,,Solidarności”, które popierat"

Konferencja Episkopatu Polski akcentowała jednak problemy społeczne związane z transformacją gospodarczą. Zwracała uwagę na potrzebę obecności Kościoła wśród bezrobotnych. Podkreślała, że problemy społeczne powodują apatię i zniechęcenie wykorzystywane do manipulacji społecznej przez tych, którzy są odpowiedzialni za długotrwałą ruinę ekonomiczną Polski ${ }^{5}$.

Po upadku komunizmu - pisała Aniela Dylus - w niektórych listach pasterskich Episkopat artykułowat ogólne poparcie prowadzonych reform. Na przykład w maju 1990 roku domagat się, aby nie naktadano na społeczeństwo nadmiernych ciężarów i aby równomiernie rozkładano je na wszystkich. W październiku 1992 roku biskupi z aprobata konstatowali ksztaltowanie się nowych struktur la$d u$ społecznego. Sygnalizowali jednocześnie, że pojawiające się zagrożenia w postaci bezrobocia oraz ubożenia społeczeństwa, zwłaszcza ludzi starych, niepetnosprawnych $i$ rodzin wielodzietnych, nie sa nieodzownym nastepstwem procesów przemian 6 .

\footnotetext{
${ }^{2}$ M. Bałtowski, M. Miszewski, Transformacja gospodarcza w Polsce, PWN, Warszawa 2006, s. 328.

3 A. Dylus, Przekształcenia własnościowe $w$ Polsce $w$ świetle nauczania społecznego Kościoła, „Chrześcijanin w Świecie” 1994, rok 24, nr 2-3 (197-198), s. 37.

${ }^{4}$ Cyt. za: T. Pieronek, Kościót i gospodarka, „Ład”, 30 października 1994 [w:] Spór o Polskę 1989-99. Wybór tekstów prasowych, wstęp, wybór i układ P. Śpiewak, Wydawnictwo Naukowe PWN, Warszawa 2000 , s. 645.

${ }^{5}$ Komunikat z 248. Konferencji Plenarnej Episkopatu Polski, Łódź, 23 czerwca 1991 roku, „Tygodnik Powszechny" 1991, Nr 27 (2191), 7 lipca, s. 2.

${ }^{6}$ A. Dylus, Przekształcenia własnościowe $w$ Polsce..., s. 37. W komunikacie z 239. Konferencji Plenarnej Episkopatu Polski, która obradowała w dniach 7-8 marca 1990 roku w Warszawie, podkreślono, że władza państwowa powinna dołożyć wszelkich starań, aby koszty społeczne przemian były
} 
Konferencja Episkopatu Polski krytycznie oceniała sytuację społeczną w okresie transformacji ${ }^{7}$. Wskazywała na potrzebę znalezienia sposobów, które pomogłyby rozbić bariery społecznej obcości, izolacji, obojętności ${ }^{8}$. W procesie przemian politycznych i gospodarczych powinna być uwzględniona chrześcijańska zasada dobra wspólnego, na które w skali państwa składa się dobro wszystkich grup społecznych, a przede wszystkim rodziny jako podstawowej komórki społecznej. Istotny jest także obecny w nauczaniu społecznym Kościoła postulat słusznej płacy, czyli takiej, która wystarczy na godziwe utrzymanie, a także na potrzebę zapewnienia opieki zdrowotnej i oświaty na właściwym poziomie oraz podjęcia działań na rzecz powszechnego zatrudnienia. Realizację dobra wspólnego należy wiązać $\mathrm{z}$ niedopuszczaniem do ukształtowania się uprzywilejowanych grup społecznych, odpowiednim dostosowaniem płac do cen towarów, udostępnieniem dóbr kulturalnych jak największej części społeczeństwa, likwidacją albo co najmniej ograniczeniem dysproporcji wśród różnych sektorów gospodarki. Produkcję dóbr należy dostosować do produkcji usług konsumpcyjnych, głównie tych, które są świadczone przez władze publiczne, sposób produkcji dostosować do rozwoju nauki i techniki i dbać o to, żeby z dobrobytu mogły korzystać również następne pokolenia9 ${ }^{9}$.

Przedstawiciele polskiej hierarchii kościelnej podkreślali, że kondycja moralna społeczeństwa też pozostawia wiele do życzenia. Chociaż zostało ono wyzwolone z urzędowego ateizmu, to jednak duża jego część żyje tak, jakby Boga nie było, zatruwana przez zakamuflowany ateizm, laicyzm i zorganizowany materializm praktyczny. Chrześcijanie są narażeni na inwazję liberalizmu moralnego, stają wobec pytań: jak mają żyć, kogo słuchać i na jakim fundamencie budować przyszłość $^{10}$. Biskupi zwracali uwagę na pogarszanie się stopy życiowej rodzin, podkreślając, że brakuje właściwej polityki społecznej, zasiłki są za niskie, jednakowe dla wszystkich i nie uwzględniają rzeczywistych potrzeb rodzin. Lansowanie wizji „kraju dla silnych” również negatywnie wpływało na warunki rodzinne. Mówili wręcz o karaniu rodziców za zrodzenie i wychowanie potomstwa gwałtownym spadkiem stopy życiowej. Sytuacji rodziny nie sprzyjały, będące od dawna proble-

rozkładane możliwie proporcjonalnie, $\mathrm{z}$ uwzględnieniem potrzeb grup najsłabszych i najbiedniejszych. Cf. Komunikat z 239. Konferencji Plenarnej Episkopatu Polski, Warszawa, dnia 8 marca 1990 roku, „Tygodnik Powszechny” 1990, nr 11 (2125), 18 marca, s. 2. Z kolei w komunikacie z 240. Konferencji Plenarnej, która odbyła się w dniach 30 kwietnia - 2 maja 1990 roku w Warszawie, zawarte zostało następujące sformułowanie: Ciężary nakładane na społeczeństwo nie powinny być jednak bardziej dotkliwe i dtużej trwajace niż jest to konieczne. Cf. Komunikat z 240. Konferencji Plenarnej Episkopatu Polski, Warszawa, dnia 2 maja 1990 roku, ,Tygodnik Powszechny” 1990, nr 19, 13 maja, s. 2.

${ }^{7}$ Wyzwolenie idzie przez rodzinę. List biskupów polskich na uroczystość Świętej Rodziny 1992 r., Jasna Góra, dnia 27 listopada 1992 r., Podpisali: Kardynałowie, Arcybiskupi i Biskupi obecni na 259. Konferencji Plenarnej Episkopatu Polski [w:] Listy pasterskie Episkopatu Polski 1945-2000, vol. 1-2, bp P. Libera, ks. A. Rybicki CSMA, ks. S. Łącki CSMA, Wydawnictwo Michalineum, Marki 2003, s. 1811 (dalej: Listy pasterskie).

${ }^{8}$ List Episkopatu Polski na uroczystość NMP Królowej Polski 3 maja 1993 r., Warszawa, dnia 23 marca 1993 r. [w:] Listy pasterskie..., s. 1819.

${ }^{9}$ Stowo biskupów polskich $w$ sprawie wyborów do parlamentu, Olsztyn, dnia 19 czerwca 1993 r., 262. Konferencja Plenarna Episkopatu Polski [w:] Listy pasterskie..., s. 1823-1824.

${ }^{10} \mathrm{Na}$ dzień zawierzenia Polski Najświętszej Maryi Pannie 26 VIII 1993, Olsztyn, dnia 19 czerwca 1993 r., 262. Konferencja Plenarna Episkopatu Polski [w:] Listy pasterskie..., s. 1826-1827. 
mem Europy Zachodniej, cywilizacja pieniądza, kultura dobrobytu i konsumpcjonizm. Są to zjawiska przekraczające granice państw i mające zgubny wpływ na sytuację demograficzną Europy ${ }^{11}$.

Konferencja Episkopatu Polski twierdziła, że ewangelizacja jest potrzebna także w życiu społeczno-gospodarczym. Realizujący dzieło ewangelizacji Kościół bywa często mylnie postrzegany jako podmiot życia politycznego, mimo że jest jedynie stróżem porządku moralnego i sumieniem krytycznym ${ }^{12}$. Podkreślała, że nie da się usprawiedliwiać tolerancji wobec łamania praw człowieka, naruszania zasad sprawiedliwości społecznej, egoistycznego podejmowania działań wymierzonych w dobro wspólne oraz lekceważenia elementarnych zasad moralności ${ }^{13}$. Przekształcenia własnościowe doprowadziły do zahamowania produkcji i wzrostu bezrobocia; bogacenia się jednych i staczania się w nędzę drugich, a walka o zdobycie władzy szła w parze $\mathrm{z}$ apatią i wycofywaniem się z życia społecznego ${ }^{14}$.

Konferencja Episkopatu zaznaczała, że Polacy powinni przestać postrzegać państwo jako instytucję opiekuńczą, a nabrać przekonania, że są podmiotem praw i obowiązków. Nie świadczy o sile państwa dominacja polityki nad gospodarką, lecz samodzielność obywateli, również w zakresie inicjatyw gospodarczych. Przekształcenia własnościowe nie mogą powodować strachu obywateli o przyszłość. Społeczeństwo powinno być na bieżąco informowane co do ich dalszych i bliższych skutków. Biskupi ostrzegali, że wykorzystywanie bezradności obywatelskiej obróci się kiedyś przeciwko sprawcom takich przemian ${ }^{15}$.

Dbałość o dobro wspólne powinna mieć charakter twórczy, a nie ograniczać się do krytyki proponowanych rozwiązań. Powinnością władzy państwowej jest realne zaangażowanie w budowanie dobra wspólnego, a tym samym rezygnacja z wykorzystywania instytucji państwowych dla własnych lub grupowych interesów ${ }^{16}$. Każde państwo demokratyczne powinno zachowywać podstawowe normy etyczne w ustawodawstwie i życiu publicznym. Samo sformułowanie norm prawnych przy jednoczesnym unikaniu odpowiedzi na pytania dotyczące ich uzasadnienia, czy to $\mathrm{w}$ wierze religijnej, czy w uniwersalnych zasadach etycznych, nie zagwarantuje zachowania bądź podtrzymywania ładu moralnego. Brak oparcia życia społecznego na gruncie norm i wartości powoduje jego niestabilność ${ }^{17}$.

\footnotetext{
${ }^{11}$ Na uroczystość Świętej Rodziny: „, Wypetnić wszystko wedlug prawa Bożego”, Jasna Góra, dnia 25 listopada 1993 r., 265. Konferencja Plenarna Episkopatu Polski [w:] Listy pasterskie..., s. 1841.

${ }^{12}$ List biskupów polskich: Akcja Katolicka w stużbie nowej ewangelizacji, Szczecin, dnia 17 czerwca 1995 r., 277. Konferencja Plenarna Episkopatu Polski [w:] Listy pasterskie..., s. 1906.

${ }^{13}$ Orędzie biskupów polskich o potrzebie dialogu i tolerancji w warunkach budowy demokracji, Wigry, dnia 15-16 września 1995 r., 279. Konferencja Plenarna Episkopatu Polski [w:] Listy pasterskie..., s. 1931-1933.

${ }^{14}$ A. Dylus, Trudna wolność katolików w Polsce, „Przegląd Powszechny” 1993(12), nr 868, s. 365.

${ }^{15}$ List biskupów Polski o roli katolików w procesie przeksztatceń polskiego rolnictwa i przeobrażeń spotecznych wsi i matych miast, Warszawa, dnia 17 marca 1995 r., 275. Konferencja Plenarna Episkopatu Polski [w:] Listy pasterskie..., s. 1893.

${ }^{16}$ Komunikat z 303. Zebrania Plenarnego Konferencji Episkopatu Polski, Podpisali: Kardynałowie, Arcybiskupi i Biskupi zebrani na 303. Zebraniu Plenarnym Konferencji Episkopatu Polski, Warszawa, dnia 2 marca 2000 r., http://www.opoka.org.pl/biblioteka/W/WE/kep/komunikat303.html, (data dostępu: 12.09.2013).

${ }^{17} O$ wartościach chrześcijańskich $w$ życiu spoleczeństwa i narodu, Warszawa, dnia 30 kwietnia 1993 r., 261. Konferencja Plenarna Episkopatu Polski [w:] Listy pasterskie..., s. 2464.
} 
Biskupi uznali, że społeczeństwo zdawało sobie sprawę z trudności przemian systemowych, ale ponosiło bardzo wysokie koszty. Szczególnie dotknięci byli mieszkańcy małych miast, bezrobotni, bezdomni, ludzie zepchnięci na margines biedy materialnej, którym nie wystarcza środków do życia. Bardzo trudna stała się sytuacja rolników, a w największym stopniu pracowników zlikwidowanych Państwowych Gospodarstw Rolnych, po upadku których nie stworzono żadnych sensownych struktur organizacyjnych. Miernikiem pracy stał się zysk, a nie godność człowieka ${ }^{18}$. Rzeczywistość gospodarczą i społeczną zdominowało traktowanie ekonomii i sukcesów finansowych jako najwyższych wartości oraz upowszechnianie opinii, że w polityce i ekonomii nie obowiązują żadne wartości. Skutkowało to żenującym poziomem konfliktów politycznych i wzrastającą liczbą przestępstw gospodarczych. Najczęściej spotykanymi elementami rozgrywek politycznych stały się nienawiść, intryga, nieufność i nieuzasadnione oskarżenia, a religię traktowano czysto instrumentalnie. Interesy partyjne stały się ważniejsze od interesów narodowych. Spowodowany w ten sposób chaos moralny prowadził do zacierania różnic między bohaterstwem a zdradą, wiernością i konformizmem $^{19}$

Konferencja Episkopatu Polski wyrażała wdzięczność wszystkim, którzy podjęli trud reform oraz zwracała uwagę na niezdolność elit politycznych do wypracowania długofalowej strategii wychodzenia z kryzysu. Przyczynił się do tego zanik moralności wielu przedstawicieli życia publicznego, przejawiający się w powszechnej korupcji i dążeniu do jak najszybszej poprawy statusu społecznego. W konsekwencji doszło do kryzysu idei dobra wspólnego i wzrostu przestępczości. Biskupi odnotowali kilka sukcesów transformacji, ale podkreślali, że Polska znalazła się na progu trzeciego tysiąclecia w sytuacji poważnego kryzysu, który jest widoczny $w$ postawach moralnych, zachowaniach społecznych, a w sferze gospodarczej w finansach publicznych, na rynku pracy i w szybko postępującym rozwarstwieniu społecznym. Wszystko to wywołało jeszcze większe niezadowolenie społeczne, apatię i pogłębiającą się niewiarę w lepszą przyszłośćc ${ }^{20}$.

Kościół zabiera głos nie dlatego, że rości sobie prawo do wydawania ekspertyz w sprawach społecznych, politycznych czy gospodarczych. Wychodzi z założenia, że wyznawana wiara powinna mieć konsekwencje w szeroko rozumianym życiu społecznym. Kościół jest zobowiązany do ukazywania grzechów społecznych, które powodują ogromne rozwarstwienie społeczne między bogactwem a nędzą. Hierarchowie podkreślali, że wypowiadając się na temat nowej „kwestii społecznej" Kościół nie liczy na żadne korzyści i przywileje i nie chce nikomu narzucać swojej koncepcji ${ }^{21}$.

\footnotetext{
${ }^{18}$ List pasterski. Uświęcenie czasu pracy i wakacji w Duchu Świętym, Pelplin, dnia 5 czerwca 1998 r., Kardynałowie, Arcybiskupi i Biskupi obecni na 295. Zebraniu Plenarnym Konferencji Episkopatu Polski [w:] Listy pasterskie..., s. 2063.

${ }^{19}$ O wartościach chrześcijańskich w życiu spoleczeństwa ..., op. cit., s. 2467.

${ }^{20}$ Ibidem

${ }^{21}$ Komunikat z 321. Zebrania Plenarnego Konferencji Episkopatu Polski, Kardynałowie, Arcybiskupi i Biskupi zebrani na 321. Zebraniu Plenarnym Konferencji Episkopatu Polski, Warszawa, 12 marca 2003 r., „L'Osservatore Romano” 2003, Rok XXIV, nr 5 (253), s. 57.
} 


\section{Problem bezrobocia}

Transformacji gospodarczej towarzyszyły zjawiska, które stanowiły znaczące zagrożenie dla wolności, gdyż spowodowały biedę, niepewność, zachwianie poczucia bezpieczeństwa, strach, utratę orientacji i sensu. Jedne z nich są charakterystyczne dla budowania nowego ustroju: bezrobocie, bezdomność, dysproporcje w standardzie życia, załamanie się opiekuńczości państwa. Z kolei zjawiskami specyficznymi dla polskiej transformacji były: lęk przed napływem obcego kapitału, przed wyzyskiem ze strony obcych oraz przed wyprzedażą polskiego majątku i ziemi ${ }^{22}$.

Konferencja Episkopatu stała na stanowisku, że nie może wykazywać obojętności na wzrastające w niektórych warstwach społecznych poczucie krzywdy i społecznej degradacji, więc występuje w roli rzecznika sprawiedliwości, solidarności społecznej oraz obrońcy tych, których niesprawiedliwość dotknęła w największym stopniu ${ }^{23}$.

W 1992 roku było prawie 2,5 miliona bezrobotnych, wśród których przeważała młodzież. Bezrobocie wpływało destruktywnie na życie rodzinne, ograniczało perspektywy życiowe i w konsekwencji prowadziło do masowego ubożenia społeczeństwa. Powiększała się grupa ludzi, których dochody nie pozwalały na osiągnięcie minimum egzystencji. Byli to głownie ludzie starsi, rodziny wielodzietne, osoby samotnie wychowujące dzieci oraz niepełnosprawni fizycznie i umysłowo.

Nie wolno tej sprawy - czytamy w liście Episkopatu zatytułowanym „Wspólna troska chrześcijańskiego narodu o własną Ojczyznę" - pozostawić swemu biegowi, mówiąc, że sa to nieodzowne następstwa procesu przekształceń gospodarczych. Jeśli tak jest, to tym bardziej trzeba poszukiwać sposobów zmniejszenia tego zła, zwłaszcza w konkretnych wypadkach. Z satysfakcja stwierdzamy, że władze państwowe oraz zwiazki zawodowe $z$ wielka troska poszukuja właściwych rozwiazań, które uwzględniatyby dobro poszczególnych ludzi, grup spotecznych, jak wreszcie dobro państwa, czyli nas wszystkich ${ }^{24}$.

Bezrobocie stało się zagrożeniem dla pokoju społecznego i demokracji. Społeczeństwo stanęło przed nieznanymi wcześniej problemami, dotąd rozwiązywanymi zazwyczaj przez państwo, którego zadaniem było zagwarantowanie miejsc $\operatorname{pracy}^{25}$.

Ta nowa „kwestia społeczna” - pisała Aniela Dylus - niewatpliwie ma wielorakie oblicza. Trudna sytuacja na rynku pracy dodatkowo negatywnie rzutuje na stosunki pracy. Pracownicy szantażowani groźba zwolnienia zmuszani bywaja do akceptacji niegodziwych warunków pracy. Wyrażaja zgodę na niesprawie-

\footnotetext{
${ }^{22}$ A. Dylus, Trudna wolność katolików..., s. 364.

${ }^{23}$ List biskupów polskich: Akcja Katolicka $w$ stużbie nowej ewangelizacji, Szczecin, dnia 17 czerwca 1995 r., 277. Konferencja Plenarna Episkopatu Polski [w:] Listy pasterskie..., s. 1906.

${ }^{24}$ Wielka troska chrześcijańskiego narodu o własna Ojczyznę, Warszawa, dnia 16 października 1992 r., 258. Konferencja Plenarna Episkopatu Polski [w:] Listy pasterskie..., s. 1805.

${ }^{25}$ A. Dylus, Kościót wobec bezrobocia: czy i jak „pocieszać”, „Znak” 2000, nr 537 (2), s. 5.
} 
dliwe wynagrodzenie, brak zabezpieczenia socjalnego, fatszowanie danych dotyczących zarobków (by obniżyć koszty ubezpieczenia społecznego) $i$ w ogóle na przedmiotowe traktowanie ${ }^{26}$.

Negatywne konsekwencje transformacji przyczyniły się do wzrostu patologii społecznej, przestępczości i brutalności w relacjach międzyludzkich. Rozwiązanie tego problemu to nie tylko zadanie państwa, ale i całego społeczeństwa. W pierwszej kolejności należy odbudować etos pracy obciążony naleciałościami poprzedniego systemu. Za przekształceniami gospodarczymi powinny pójść możliwości uzyskiwania nowych kwalifikacji, które ułatwiłyby znalezienie pracy. Konferencja Episkopatu Polski zwracała się też do obywateli o uczciwość wobec państwa. Naganne jest pobieranie zasiłku dla bezrobotnych, gdy można podjąć pracę. Jest to okradanie państwa i działanie na szkodę dobra wspólnego. Biskupi apelowali, aby główną zasadą realizowanych reform społecznych była dbałość o człowieka, sprawiedliwość społeczną, równość szans dla każdego i integralny rozwój narodu ${ }^{27}$.

Konferencja Episkopatu podkreślała, że bezrobocie dotyka znaczną część Polaków, a perspektywy na przyszłość nie są optymistyczne. Rozwiązanie tej nowej „kwestii społecznej” jest uzależnione od zbudowania nowej kultury życia i pracy, które postawią człowieka w centrum wszystkich przedsięwzięć społecznych ${ }^{28}$. Tymczasem coraz więcej dziedzin życia społecznego wskazuje, że zagrożona jest godność człowieka i jego wszechstronny rozwój. Bezrobocie przybrało postać klęski społecznej i stało się sprawdzianem weryfikującym rozwój i postęp społeczny ${ }^{29}$.

Nauczanie społeczne Kościoła wychodzi z postulatem dokonania rewizji rozumienia pojęcia rozwoju, który błędnie utożsamiany jest jedynie ze wzrostem materialnym. Jednak wzrost gospodarczy niekoniecznie musi oznaczać wzrost zatrudnienia. Bezrobocie można traktować jako miernik kryzysu gospodarczego, który może pojawiać się w krajach o gospodarce wolnorynkowej, ale jest to spojrzenie jedynie z ekonomicznego punktu widzenia i przy założeniu określonego systemu gospodarczego, które prowadzi do zacieśniania samego pojęcia bezrobocia do tzw. bezrobocia niedobrowolnego, czyli sytuacji społeczno-ekonomicznej, w której wielkie rzesze ludzi są gotowe pracować za każde, nawet bardzo niskie wynagrodzenie, ale nie ma dla nich po prostu miejsc pracy. Taka sytuacja może być wynikiem niedorozwoju całej gospodarki albo kryzysu ${ }^{30}$.

\footnotetext{
${ }^{26}$ Ibidem.

${ }^{27}$ Komunikat z 303. Zebrania Plenarnego Konferencji Episkopatu Polski, Podpisali: Kardynałowie, Arcybiskupi i Biskupi zebrani na 303. Zebraniu Plenarnym Konferencji Episkopatu Polski, Warszawa, dnia 2 marca 2000 r., http://www.opoka.org.pl/biblioteka/W/WE/kep/komunikat303.html, (data dostępu: 12.09.2013).

${ }^{28}$ W trosce o nowa kulturę życia i pracy, List społeczny Konferencji Episkopatu Polski, 30.10.2001, http://episkopat.pl/?a=dokumentyKEP\&doc=wtrosce, (data dostępu: 19.02.2011).

${ }^{29}$ Kościół katolicki na Śląsku wobec bezrobocia, Damian Zimoń, Arcybiskup Metropolita Katowicki, Katowice, w Uroczystość św. Józefa, Oblubieńca Najświętszej Maryi Panny, 19 marca 2001, http:// www.episkopat.pl/?a=dokumentyKEP\&doc=bezrobocie1, (data dostępu: 19.02.2011).

${ }^{30}$ Ibidem.
} 
Przedstawiciele hierarchii kościelnej zwracali uwagę na coraz bardziej zauważalne zjawisko wykluczenia społecznego, będące konsekwencją gwałtownego powiększania się różnicy w sferze materialnej pomiędzy beneficjentami przemian i tymi, którzy stali się ich ofiarami. Narastające poczucie społecznej niesprawiedliwości potęgowane było także tym, że znaczna część korzystających na przemianach gospodarczych i politycznych to jednocześnie sprawcy nieszczęść społecznych. Wszystko to groziło utratą identyfikacji sporej części Polaków z państwem polskim ${ }^{31}$.

Biskupi wyrażali niepokój z powodu oznak głębokiego kryzysu państwa. Należy jak najszybciej wyeliminować z życia społecznego przejawy korupcji, prywaty, kierowania się partyjnym interesem czy też pogoni za zyskiem za wszelką cenę. Najgorsze w tym wszystkim jest to, że niektórzy Polacy uznają te negatywne zjawiska życia społecznego za normalne i dbają jedynie o własny zysk, nie przejawiając przy tym jakichkolwiek skrupułów moralnych ${ }^{32}$.

Wielkie bezrobocie, korupcja, brak wizji, a także woli rozwiązywania problemów społecznych wśród ekipy rządzącej prowadziły do poważnych napięć społecznych. W takiej sytuacji biskupi apelowali do polityków, aby kierowali się przede wszystkim dobrem wspólnym, a nie egoistycznymi interesami jednostek, grup społecznych czy też partyjnych ${ }^{33}$.

Wspólnota Kościoła - czytamy w liście Episkopatu - wedlug swoich możliwości pomaga i będzie pomagała ludziom dotkniętym biedą. Z cała moca biskupi jednak podkreślaja, że rozwiazanie kwestii ekonomicznych i społecznych, a zwłaszcza bezrobocia, należy przede wszystkim do kompetentnych struktur państwowych ${ }^{34}$.

Niestety, zdarzało się, że dobroczynność bywała pojmowana instrumentalnie, jako środek do promocji rynkowej własnej firmy. Kościół przypomina o godności ludzi biednych i potrzebie poszukiwania sprawiedliwych i stabilnych rozwiązań problemów społecznych. Ludzie biedni mają prawo oczekiwać, żeby stworzono im odpowiednie warunki do funkcjonowania w życiu społecznym, co jest równie ważne, jak przydzielanie im doraźnych zapomóg ${ }^{35}$.

Konferencja Episkopatu Polski wskazywała na negatywne pozostałości systemu opartego na ideologii marksistowskiej, które utrudniały budowanie demokracji. Były to przede wszystkim: brak umiejętności potrzebnych dla stworzenia

\footnotetext{
${ }^{31}$ Ibidem.

${ }^{32}$ Komunikat z 323. Zebrania Plenarnego Konferencji Episkopatu Polski, Kardynałowie, Arcybiskupi i Biskupi obecni na 323. Zebraniu Plenarnym Konferencji Episkopatu Polski, Paradyż, dnia 15 czerwca 2003 r., „L'Osservatore Romano” 2003, Rok XXIV, nr 7-8 (255), s. 58.

${ }_{33}$ Stowo Rady Stałej Konferencji Episkopatu Polski oraz Biskupów Diecezjalnych, Kardynałowie, Arcybiskupi i Biskupi, Jasna Góra, 25 sierpnia 2003 r., „L'Osservatore Romano” 2003, Rok XXIV, nr 10 (257), s. 61.

${ }^{34}$ Ibidem.

${ }^{35}$ List pasterski: O radzie i ślubie ewangelicznego ubóstwa na niedzielę przed IX Światowym Dniem Życia Konsekrowanego (30 stycznia 2005 r.), Bp A. Dzięga, Biskup Sandomierski, Przewodniczący Komisji Konferencji Episkopatu Polski ds. Instytutów Życia Konsekrowanego i Stowarzyszeń Życia Apostolskiego, Sandomierz, w Uroczystość Objawienia Pańskiego, 6 stycznia 2005 roku, http:// www.episkopat.pl/?a=dokumentyKEP\&doc=2005119_0, (data dostępu: 27.09.2011).
} 
demokracji, kultury dyskusji i sporów politycznych, podejrzliwość, brak cierpliwości, nietolerancyjność, a także brak wiedzy o społeczeństwie, regułach życia politycznego i inicjatywy gospodarczej. Doprowadziły one do pojawienia się społecznej bierności, frustracji, beznadziejności i skłonności do emigracji ${ }^{36}$. Okazało się, że wolność, demokracja i gospodarka oparta na zdrowych zasadach ekonomicznych wymagają wielu poświęceń i nie mogą być zbudowane w krótkim czasie. Nie rozliczono też sprawców niesprawiedliwości poprzedniego systemu, co więcej, znaczna część społeczeństwa jest przekonana, że korzystają oni w wolnym państwie w sposób bezkarny z uzyskanych wcześniej przywilejów. Dominowały prywata i korupcja, prowadzące do zatracenia wrażliwości na dobro wspólne, dobro osoby ludzkiej i kierowanie się interesami partyjnymi zarówno wśród indywidualnych polityków, jaki i całych środowisk politycznych ${ }^{37}$.

Przemiany gospodarcze przyczyniły się do powstania wielu obszarów biedy. Niewielka część społeczeństwa osiągnęła dobrobyt i staje się coraz bardziej bogata, ale znacznie pogłębiły się różnice pomiędzy bogatymi i żyjącymi na skraju nędzy ${ }^{38}$.

Obok powodów do radości i dumy - pisali biskupi - w naszej Ojczyźnie jest też wiele bólu, cierpienia i rozczarowania, spowodowanego zachodzacymi przemianami. Ból ten czasami ujawnia się w formie niepokojów, strajków czy demonstracji. Wśród form protestów stosowanych $w$ spoleczeństwie demokratycznym strajki to ostateczność. Wtadze jednak powinny szybciej dostrzegać potrzeby spoleczeństwa $i$ wychodzić im naprzeciw. Taka jest rola i obowiązek państwa. (...) Dostrzegamy wysitki wladz państwowych, zwiazane z fundamentalnymi reformami, bez których przyszłość Polski jest nie do pomyślenia. Los reform, których konieczności się na ogót nie kwestionuje, zależy od stopnia zaangażowania catego narodu $u^{39}$.

Konferencja Episkopatu Polski krytykowała lansowanie radykalnej ideologii kapitalizmu, według której rozwiązanie wszelkich problemów społecznych i gospodarczych jest możliwe tylko dzięki systemowi opartemu na swobodnej grze sił rynkowych, a wszelkie inne metody są skazane na niepowodzenie. Doprowadziło to do wyniszczenia materialnego i moralnego na skutek wypaczenia najbardziej elementarnych stosunków gospodarczych i zdezawuowania takich cech, jak: pracowitość, prawdomówność, wiarygodność, inicjatywa ${ }^{40}$.

Po dwunastu latach przemian systemowych w Polsce - pisali biskupi - musimy stwierdzić, że wielu ludzi odpowiedzialnych za ksztalt życia publicznego bezkrytycznie uwierzyło, że upadek marksizmu oznacza automatycznie powstanie

\footnotetext{
${ }^{36}$ List Pasterski Episkopatu Polski o chrześcijańskim etosie pracy, Jasna Góra, dnia 30 listopada 1990 r., 244. Konferencja Plenarna Episkopatu Polski [w:] Listy pasterskie ..., op. cit., s. 1698.

${ }^{37}$ Słowo biskupów polskich na Wielki Jubileusz Narodzenia Zbawiciela, Jasna Góra, dnia 25 listopada 1999 r., Kardynałowie, Arcybiskupi i Biskupi zgromadzeni na 302. Zebraniu Plenarnym Konferencji Episkopatu Polski [w:] Listy pasterskie..., op. cit., s. 2105.

${ }^{38}$ Ibidem, s. 2103.

${ }^{39}$ Ibidem, s. 2103-2104.

${ }^{40} \mathrm{~W}$ trosce o nową kulturę życia..., op. cit., http://episkopat.pl/?a=dokumentyKEP\&doc=wtrosce, (data dostępu: 19.02.2011).
} 
sprawiedliwego spoleczeństwa oraz zaufało mechanizmom wolnorynkowym, które we wszystkich dziedzinach miaty zagwarantować dobro każdego i wszystkich. $W$ miejsce ideologii kolektywnej pojawiła się wypaczona wersja liberalizmu, która wyrodziła się w liberalna ideologie głoszona często w jej zwulgaryzowanej formie, ujmujacej rzeczywistość niemal wyłacznie w kategoriach ekonomicznych. W ten sposób niezbędny dla kraju rozwój utożsamiano jedynie ze wzrostem gospodarczym ${ }^{41}$.

\section{Podsumowanie}

Początkowo Konferencja Episkopatu Polski była bardzo powściągliwa w formułowaniu ocen transformacji gospodarczej, obawiając się oskarżeń o polityczne zaangażowanie Kościoła i nie chcąc występować przeciwko rządom wywodzącym się ze środowisk opozycji antykomunistycznej. Jednak już w roku 1992 dominowało stanowisko krytyczne. Negatywnie oceniano polską transformację gospodarczą, zwracając uwagę na ogromne koszty społeczne przemian i towarzyszący im upadek moralności.

Konferencja Episkopatu Polski twierdziła, że budowanie nowego systemu cechowało się nagminnym lekceważeniem podstawowych wartości i łamaniem zasad moralności chrześcijańskiej. Przestrzegała wiernych, że moralność katolicka jest nie do pogodzenia z jakąkolwiek formą korupcji. Podkreślała, że państwo przekształcono w oligarchiczną grę grup interesów, co stanowi podważenie zasady praworządności władzy i szkodzi obywatelom. Nawoływała do jak najszybszego zerwania $\mathrm{z}$ takimi praktykami i zorganizowania autentycznego państwa prawa ${ }^{42}$.

Gospodarka wolnorynkowa nie została oparta na zasadach etycznych, przez co zamieniła się w bezwzględną walkę. Jej koszty poniosła biedniejąca i pozbawiona szans poprawy bytu część społeczeństwa, która nie potrafiła się znaleźć w nowej rzeczywistości. Konferencja Episkopatu Polski twierdziła, że zapanowało niepisane przyzwolenie na egoistyczne urządzanie sobie życia bez żadnych moralnych barier i bez względu na szkody, jakie to przynosi wspólnocie. Krytykowała model konsumpcyjny, relatywizm, apoteozę sukcesu, bogactwa oraz wizję łatwego życia bez rozterek sumienia.

Biskupi wzywali ludzi wierzących do zwiększania aktywności w życiu politycznym, przypominając, że jest to prawo i obowiązek ludzi świeckich wynikający z chrześcijańskiej odpowiedzialności za ojczyznę ${ }^{43}$. Spory i konflikty polityczne są charakterystyczne dla demokracji. Jest to konsekwencja konkurencji różnych wizji rzeczywistości społeczno-politycznej i gospodarczej, która podlega nieustannej redefinicji. Konkurencja ta musi jednak przebiegać według pewnych reguł, które w polskiej demokracji nie są przestrzegane.

\footnotetext{
${ }^{41}$ Ibidem.

${ }^{42}$ Komunikat z 321. Zebrania Plenarnego..., op. cit., s. 57.

${ }^{43}$ B. Górowska, Konferencja Episkopatu Polski, W trosce o człowieka i dobro wspólne, Tarnów 2012, s. 72, Recenzja, Ośrodek Analiz Politologicznych Uniwersytetu Warszawskiego, 8/2013, http://oapuw. $\mathrm{pl}$ /wp-content/uploads/2013/08/Górowska-B.pdf, s. 249, (data dostępu: 12.09.2013).
} 
Konferencja Episkopatu Polski piętnowała atakowanie Kościoła w celu osiągnięcia korzyści politycznych. Zdecydowanie sprzeciwiała się ośmieszaniu jego nauki moralnej, działalności, niesprawiedliwemu oskarżaniu, a przy tym szerzeniu antyklerykalizmu, uznając takie działania za nieetyczne i społecznie szkodliwe. Lansowanie w życiu politycznym rywalizacji na zasadzie przyjaciel - wróg jest nie do przyjęcia z etycznego punktu widzenia, a ponadto ma negatywny wpływ na zachowania obywateli i zniechęca do udziału w życiu politycznym, co przejawia się przede wszystkim w bardzo niskiej frekwencji w wyborach ${ }^{44}$.

\section{Bibliografia}

Bałtowski M., M. Miszewski, Transformacja gospodarcza $w$ Polsce, PWN, Warszawa 2006.

Dylus A., Kościól wobec bezrobocia: czy i jak „,pocieszać”, „Znak” 2000, nr 537 (2).

Dylus A., Przeksztatcenia własnościowe w Polsce w świetle nauczania społecznego Kościota, „Chrześcijanin w Świecie” 1994, Rok XXIV, nr 2-3.

Dylus A., Trudna wolność katolików w Polsce, „Przegląd Powszechny” 1993, vol. 12, nr 868.

Górowska B., Konferencja Episkopatu Polski, W trosce o czlowieka i dobro wspólne, Tarnów 2012, Recenzja, Ośrodek Analiz Politologicznych Uniwersytetu Warszawskiego, 8/2013, http://oapuw.pl/wp-content/uploads/2013/08/Górowska-B.pdf.

Komunikat z 239. Konferencji Plenarnej Episkopatu Polski, Warszawa, dnia 8 marca 1990 roku, ,Tygodnik Powszechny” 1990, 18 marca, nr 11 (2125).

Komunikat z 240. Konferencji Plenarnej Episkopatu Polski, Warszawa, dnia 2 maja 1990 roku, „Tygodnik Powszechny” 1990, 13 maja, nr 19.

Komunikat z 248. Konferencji Plenarnej Episkopatu Polski, Łódź, 23 czerwca 1991 roku, „Tygodnik Powszechny” 1991, 7 lipca, nr 27 (2191).

Komunikat z 303. Zebrania Plenarnego Konferencji Episkopatu Polski, Podpisali: Kardynałowie, Arcybiskupi i Biskupi zebrani na 303. Zebraniu Plenarnym Konferencji Episkopatu Polski, Warszawa, dnia 2 marca 2000 r., http://www.opoka.org.pl/bi blioteka/W/WE/kep/komunikat303.html.

Komunikat z 323. Zebrania Plenarnego Konferencji Episkopatu Polski, Kardynałowie, Arcybiskupi i Biskupi obecni na 323. Zebraniu Plenarnym Konferencji Episkopatu Polski, Paradyż, dnia 15 czerwca 2003 r., „LOsservatore Romano” 2003, Rok XXIV, nr 7-8 (255).

Kościót katolicki na Śląsu wobec bezrobocia, Damian Zimoń, Arcybiskup Metropolita Katowicki, Katowice, w Uroczystość św. Józefa, Oblubieńca Najświętszej Maryi Panny, 19 marca 2001, http://www.episkopat.pl/?a=dokumentyKEP\&doc=bez robocie1.

List biskupów Polski o roli katolików w procesie przeksztatceń polskiego rolnictwa i przeobrażeń społecznych wsi i małych miast, Warszawa, dnia 17 marca 1995 r., 275. Konferencja Plenarna Episkopatu Polski [w:] Listy pasterskie Episkopatu Polski

\footnotetext{
${ }^{44}$ Ibidem.
} 
1945-2000, t. 1-2, bp P. Libera, ks. A. Rybicki CSMA, ks. S. Łącki CSMA, Wydawnictwo Michalineum, Marki 2003.

List biskupów polskich: Akcja Katolicka w stużbie nowej ewangelizacji, Szczecin, dnia 17 czerwca 1995 r., 277. Konferencja Plenarna Episkopatu Polski [w:] Listy pasterskie Episkopatu Polski 1945-2000, t. 1-2, bp P. Libera, ks. A. Rybicki CSMA, ks. S. Łącki CSMA, Wydawnictwo Michalineum, Marki 2003.

List biskupów polskich: Akcja Katolicka w stużbie nowej ewangelizacji, Szczecin, dnia 17 czerwca 1995 r., 277. Konferencja Plenarna Episkopatu Polski [w:] Listy pasterskie Episkopatu Polski 1945-2000, t. 1-2, bp P. Libera, ks. A. Rybicki CSMA, ks. S. Łącki CSMA, Wydawnictwo Michalineum, Marki 2003.

List Episkopatu Polski na uroczystość NMP Królowej Polski 3 maja 1993 r., Warszawa, dnia 23 marca 1993 r. [w:] Listy pasterskie Episkopatu Polski 1945-2000, t. 1-2, bp P. Libera, ks. A. Rybicki CSMA, ks. S. Łącki CSMA, Wydawnictwo Michalineum, Marki 2003.

List Pasterski Episkopatu Polski o chrześcijańskim etosie pracy, Jasna Góra, dnia 30 listopada 1990 r., 244. Konferencja Plenarna Episkopatu Polski [w:] Listy pasterskie Episkopatu Polski 1945-2000, t. 1-2, bp P. Libera, ks. A. Rybicki CSMA, ks. S. Łącki CSMA, Wydawnictwo Michalineum, Marki 2003.

List pasterski. Uświęcenie czasu pracy i wakacji w Duchu Świętym, Pelplin, dnia 5 czerwca 1998 r., Kardynałowie, Arcybiskupi i Biskupi obecni na 295. Zebraniu Plenarnym Konferencji Episkopatu Polski [w:] Listy pasterskie Episkopatu Polski 1945-2000, t. 1-2, bp P. Libera, ks. A. Rybicki CSMA, ks. S. Łącki CSMA, Wydawnictwo Michalineum, Marki 2003.

List pasterski: O radzie i ślubie ewangelicznego ubóstwa na niedziele przed IX Światowym Dniem Życia Konsekrowanego (30 stycznia 2005 r.), Bp A. Dzięga, Biskup Sandomierski, Przewodniczący Komisji Konferencji Episkopatu Polski ds. Instytutów Życia Konsekrowanego i Stowarzyszeń Życia Apostolskiego, Sandomierz, w Uroczystość Objawienia Pańskiego, 6 stycznia 2005 roku, http://www.episkopat.pl/?a $=$ dokumentyKEP\&doc=2005119_0.

Na dzień zawierzenia Polski Najświętszej Maryi Pannie 26 VIII 1993, Olsztyn, dnia 19 czerwca 1993 r., 262. Konferencja Plenarna Episkopatu Polski [w:] Listy pasterskie Episkopatu Polski 1945-2000, t. 1-2, bp P. Libera, ks. A. Rybicki CSMA, ks. S. Łącki CSMA, Wydawnictwo Michalineum, Marki 2003.

Na uroczystość Świętej Rodziny: ,Wypetnić wszystko wedtug prawa Bożego”, Jasna Góra, dnia 25 listopada 1993 r., 265. Konferencja Plenarna Episkopatu Polski [w:] Listy pasterskie Episkopatu Polski 1945-2000, t. 1-2, bp P. Libera, ks. A. Rybicki CSMA, ks. S. Łącki CSMA, Wydawnictwo Michalineum, Marki 2003.

O wartościach chrześcijańskich w życiu społeczeństwa i narodu, Warszawa, dnia 30 kwietnia 1993 r., 261. Konferencja Plenarna Episkopatu Polski [w:] Listy pasterskie Episkopatu Polski 1945-2000, t. 1-2, bp P. Libera, ks. A. Rybicki CSMA, ks. S. Łącki CSMA, Wydawnictwo Michalineum, Marki 2003.

Orędzie biskupów polskich o potrzebie dialogu i tolerancji w warunkach budowy demokracji, Wigry, dnia 15-16 września 1995 r., 279. Konferencja Plenarna Episkopatu Polski [w:] Listy pasterskie Episkopatu Polski 1945-2000, t. 1-2, bp P. Libera, ks. A. Rybicki CSMA, ks. S. Łącki CSMA, Wydawnictwo Michalineum, Marki 2003. 
Pieronek T., Kościót i gospodarka, „Ład”, 30 października 1994 [w:] Spór o Polskę 198999. Wybór tekstów prasowych, wstęp, wybór i układ P. Śpiewak, PWN, Warszawa 2000.

Skowronek K., Między sacrum a profanum. Studium językoznawcze listów pasterskich Konferencji Episkopatu Polski (1945-2005), LEXIS, Kraków 2006.

Słowo biskupów polskich na Wielki Jubileusz Narodzenia Zbawiciela, Jasna Góra, dnia 25 listopada 1999 r., Kardynałowie, Arcybiskupi i Biskupi zgromadzeni na 302. Zebraniu Plenarnym Konferencji Episkopatu Polski [w:] Listy pasterskie Episkopatu Polski 1945-2000, t. 1-2, bp P. Libera, ks. A. Rybicki CSMA, ks. S. Łącki CSMA, Wydawnictwo Michalineum, Marki 2003.

Stowo biskupów polskich $w$ sprawie wyborów do parlamentu, Olsztyn, dnia 19 czerwca 1993 r., 262. Konferencja Plenarna Episkopatu Polski [w:] Listy pasterskie Episkopatu Polski 1945-2000, t. 1-2, bp P. Libera, ks. A. Rybicki CSMA, ks. S. Łącki CSMA, Wydawnictwo Michalineum, Marki 2003.

Stowo Rady Statej Konferencji Episkopatu Polski oraz Biskupów Diecezjalnych, Kardynałowie, Arcybiskupi i Biskupi, Jasna Góra, 25 sierpnia 2003 r., „L'Osservatore Romano" 2003, Rok XXIV, nr 10 (257).

$W$ trosce o nowa kulture życia i pracy, List społeczny Konferencji Episkopatu Polski, 30.10.2001, http://episkopat.pl/?a=dokumentyKEP\&doc=wtrosce.

Wielka troska chrześcijańskiego narodu o własna Ojczyznę, Warszawa, dnia 16 października 1992 r., 258. Konferencja Plenarna Episkopatu Polski [w:] Listy pasterskie Episkopatu Polski 1945-2000, t. 1-2, bp P. Libera, ks. A. Rybicki CSMA, ks. S. Łącki CSMA, Wydawnictwo Michalineum, Marki 2003.

Wyzwolenie idzie przez rodzinę. List biskupów polskich na uroczystość Świętej Rodziny 1992 r., Jasna Góra, dnia 27 listopada 1992 r., Podpisali: Kardynałowie, Arcybiskupi i Biskupi obecni na 259. Konferencji Plenarnej Episkopatu Polski [w:] Listy pasterskie Episkopatu Polski 1945-2000, t. 1-2, bp P. Libera, ks. A. Rybicki CSMA, ks. S. Łącki CSMA, Wydawnictwo Michalineum, Marki 2003. 